\title{
THE INFLUENCE OF SOME FACTORS ON CARCASS DEFECTS DURING FATTENING PERIOD INBROILERS
}

\author{
INCIDENCIA DE ALGUNOS FACTORES SOBRE DEFECTOS DE LA CANAL DE POLLOS \\ DURANTE EL ENGORDE
}

\begin{abstract}
Kun, Z. ${ }^{1}$, A.N. Uluocak ${ }^{1}$ and M. Karaman ${ }^{2 *}$
${ }^{1}$ University of Cukurova. Agriculture Faculty. Animal Science Department. 01330 Adana. Turkey.

${ }^{2}$ University of Kahramanmaras. Agriculture Faculty. Animal Science Department. 46100 Kahramanmaras. Turkey. *Corresponding author: karaman@ksu.edu.tr
\end{abstract}

\section{AdDITIONAL KEYWORDS \\ Husbandry. Animal welfare.}

\section{SUMMARY}

The aim of present study was to determine the effect of slaughtering age, stocking density, gender, litter type, feeder type and poultry house type on the possible carcass defects such as broken bones, joint defects, breast blister, blood and bruise on breast, thigh and wing, breast bruise. The incidence of these carcass defects decreased with increasing age of broiler. The incidence of broken bones, joint defects and breast bruise increased with increasing stocking density. The incidence of joint defects and blood and bruise on thigh for female were significantly higher than those for male broiler. There are no significant differences among litter type in terms of the carcass defects of broilers. There are no significant differences among type of feeder and of house in terms of incidence of carcass defects measured in this experiment. Broken bones, bruising and other defects with carcass indicate adverse animal welfare and loss in product yield. This experiment determined the nature and incidence of defects contributing to the total.

\section{RESUMEN}

El propósito de este trabajo fue determinar el efecto de la edad de sacrificio, densidad de población, sexo, tipo de yacija, tipo de alimentador y tipo de gallinero sobre posibles defectos de la canal tales como huesos rotos, defectos articulares, erosiones en la pechuga, sangre y hematomas de la pechuga, muslo o alas, hematomas de la

\author{
Palabras Clave adicionales \\ Manejo. Bienestar animal.
}

pechuga. La incidencia de estos problemas decreció al aumentar la edad del ave. La incidencia de huesos rotos, defectos articulares y hematomas en la pechuga aumentó con la densidad de población. Los defectos articulares y sangre o hematomas del muslo en las hembras fueron más frecuentes que en los machos. No se encontraron diferencias entre tipos de yacija, tipos de alimentador o tipo de gallinero. Huesos rotos, hematomas $\mathrm{u}$ otros defectos indican ausencia de bienestar y pérdidas económicas. Se determinó la contribución al total de la naturaleza e incidencia de defectos.

\section{INTRODUCTION}

The factors affecting the broiler meat quality can be examined in the three periods, fattening, slaughtering, processing periods (Gurer etal., 1991; Yalcın and Kocak, 1992). Color of poultry meat is very important because consumers associate it with the product's freshness and they decide whether or not to buy the product based on their opinion of its attractiveness. Poultry meat colour is affected by several factors such as bird age, sex, pre-slaughter conditions and processing variables. Color of meat is related to the amount of presence of muscle pigments myoglobin and hemoglobin. Another major cause of poultry meat 
discoloration is bruising (Northcutt, 1997).

The determination of the factors affecting the poultry meat quality is very important issue for the poultry industry to eliminate their possible negative effect on broiler meat quality. The poultry industry generally tries to identify where, how and when these factors affecting the poultry meat quality although this is very difficult task to determine.

The aim of present study was to determine the effect of slaughtering age, stocking density, sex, litter type, feeder type and poultry house type on the possible carcass defects in Turkey.

\section{MATERIALSAND METHODS}

Animal material was obtained from broiler producers which have contracts with KOYTUR Ltd. in Turkey, Tarsus in November 2002 and March 2003. The factors such as slaughtering age (36-40, 41-44 and 45-50 day) stocking density (11-13, 14-16 and 1720 broiler $/ \mathrm{m}^{2}$ ), gender (male and female), litter type (wood shaving, wheat straw, and rice hull), feeder type (hanging feeder, spiral feeder and automatic chain feeder) poultry house type (open sided house and controlled-environment house) on the possible carcass defects such as broken bones, joint defects, breast blister, blood and bruise on breast; thigh and wing, breast bruise (Gezertekin and Yalcın, 1999) were examined in 49 poultry houses. 100, 200, 300 and 500 broiler carcass were taken from poultry houses where their capacity of 4000,4000 $8000,8000-12000$ and 12 000-16 000 respectively. Total 8500 carcasses were evaluated for the incidence of a common array of defects at predetermined locations. Mean statistical differences were considered significant at $\mathrm{p}<0.05$.

\section{RESULTSANDDISCUSSION}

The effect of slaughtering age, stocking density and gender on the carcass defects is given in table I. The incidence of broken bones ranged from 17.3 to $26.6 \%$. The slaughtering age had a significant effect on the carcass defects. The slaughtering at 3640 day age resulted in significantly higher incidence of broken bones than that obtained at 45-50 day age. In the current study the incidence of broken bones was early stage of growing was significantly higher than that obtained late growing stage. This result is not consistent with finding of Gezertekin and Yalcın (1999) and Nicol and Scott (1990) who found that increase of broken bone in young broilers closely related with heavy carcasses.

The incidence of joint defects at 41-44 day age was significantly higher than that obtained at 45-50 day age of broilers. There is no significant difference among the incidence of breast blister obtained three different ages. However it has been reported that formation of breast blister is related to carcass weight of broilers (Mayes, 1980).

The incidences of blood and bruise on thigh, wing and breast were significantly decreased with increasing age. The incidence of blood and bruise on breast at 41-44 day age was significantly lower than that obtained at 45-50 day age. The incidences of blood and bruise on thigh and wing at 45-50 day age were significantly lower than those obtained at early growing stages. This result is in agreement with findings of Bilgili (1990) and Gezertekin and Yalcin (1999). Although the incidence of breast bruise was also decreased with increasing age the incidence of breast bruise at 41-44 day age was significantly lower that that obtained at 36-40 day age. It was reported that high incidence of bruise and blood in wings was related to electric shock during slaughtering (Summers, 2004).

The stocking density had a significant $(p<0.05)$ effect on some of carcass defects. The incidences of broken bones and joint defects increased with increasing stocking density whereas the incidence of breast bruise decreased with increasing stocking 


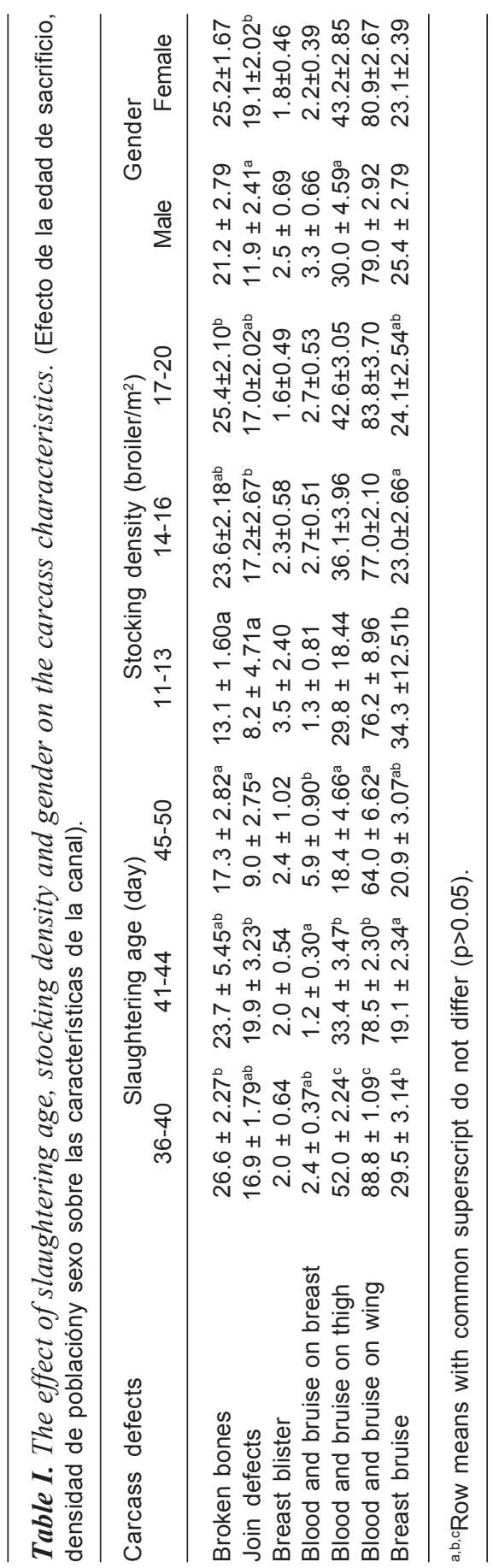

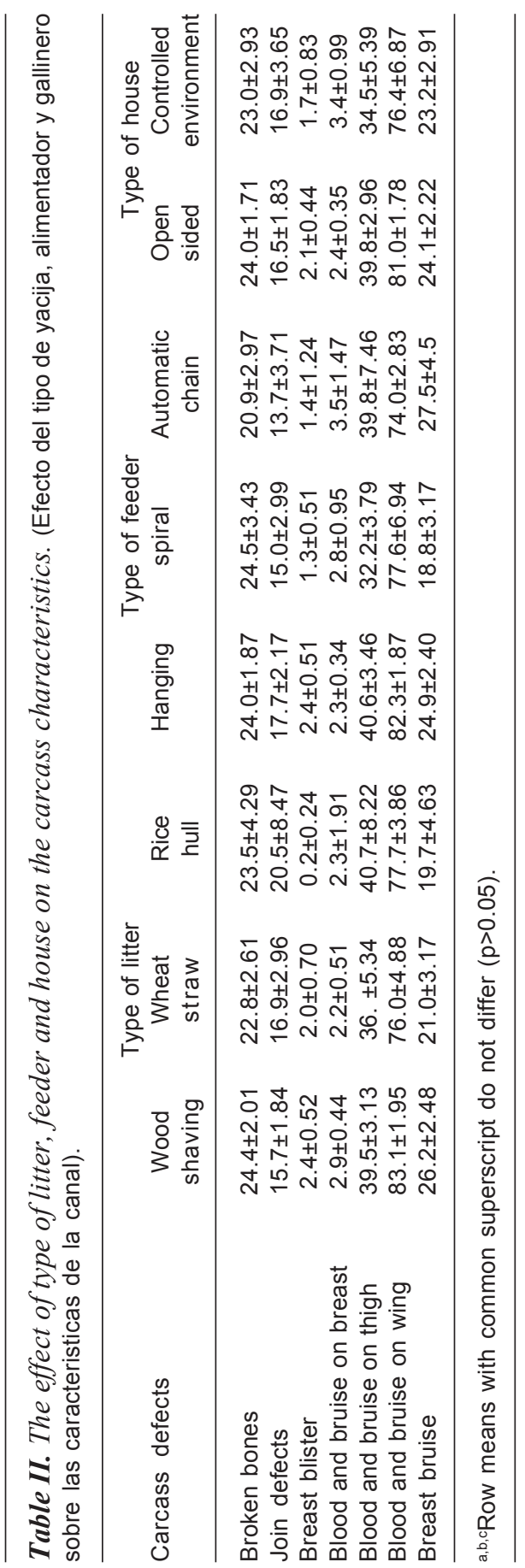




\section{KUN, ULUOCAK AND KARAMAN}

density. This result is in agreement with findings of Bilgili (1990) and Saylam and Dogan (1995). The gender had no effects on the carcass defects except for join defects and blood and bruise on thigh. The incidence of joint defects and blood and bruise on thigh for female was significantly higher than that for male. This result is in agreement with findings of Bilgili (1990) who reported those females are more sensitive than male broilers.

The effect of litter, feeder house types on the carcass defects is given in table II Litter, feeder and house types had no significant $(p>0.05)$ effect on carcass defects measured in this experiment. This result is not in agreement with findings of Kundakci and Cetin (1995) and Yalcin et al. (1995) who found that type of litter had significant effect on the breast defects. This result is

\section{REFERENCES}

Bilgili, S.F. 1990. Canlı üretimden kesime tavuk etinin kalitesi ve randimana etki eden faktörler. Uluslararasi Tavukçuluk Kongresi, 23-25.05. 1990. Istanbul, Bildiriler. p. 53-65.

Gezertekin, U. and S. Yalcın. 1999. Etlik piliçlerde karkas kusurları ile karkas agırlıgı arasındak iliskiler. VIV. Poultry. Yutav Uluslararası Tavukçuluk Fuarı ve Konferansı, 3-6.06.1999, Istanbul. Bildiriler. p. 85-92.

Gurer, C., I. Erbas and S. Ozdemir. 1991. Etlik piliçlerde altlık, nakliye ve kesim agırlıgının karkas kalite bozukluklarına etkisi, bozuklukların lokalizasyonu ve tiplerini belirlenmesi. Türk Veteriner ve Hayvancılık Derg., 15: 320-327.

Kundakci, A. and K. Cetin. 1995. Kanatl 1 eti üretiminde kalite saglama. Uludag Univ. Ziraat Fakültesi Dergisi, 11: 253-265.

Mayes, F.J. 1980. The incidence of breast blister down grading in broiler chickens. British Poultry Sci., 21: 497-504.

Nicol, C.J. and G.B. Scott. 1990. Pre-slaughter handling and transport of broiler chickens. Appl. not in agreement with finding of Yalc1n and Kocak (1992).

\section{CONCLUSION}

The incidence of broken bones, joint defects, blood and bruise on thing and wing, and breast bruising decreased with increasing age of broiler. The incidence of broken bones, joint defects and breast bruise increased with increasing stocking density. The incidence of joint defects and blood and bruise on thigh for female were significantly higher than those for male broiler. Broken bones, bruising and other defects with carcass indicate adverse animal welfare and loss in product yield. This experiment determined the nature and incidence of defects contributing to the total.

Anim. Behav. Sci., 28: 57-73.

Northcutt, J.K. 1997. Reference guide for solving poultry processing problems. The University of Georgia of Agricultural and Environmental Science. Cooperative Extension Service.

Saylam, S.K. and M. Dogan. 1995. Etlik piliç yetistiriciliginde yerlesim sıklıgının performansa etkileri üzerine bir arastırma. Uluslararası Tavukçuluk Kongresi, 24-25.05. 1995. Istanbul, Bildiriler. p. 447-458.

Summers, J. 2004. Blood and hemorrhages in broiler carcasses http://www.Poultryindustry council.ca./Factsheet/Factsheets/fact36.htm. (27.04.2004).

Yalcın, S. and C. Kocak. 1992. Etlik piliçlerde karkas niteligini etkileyen etmenler. Trakya Bölgesi 1.Hayvancılık Sempozyumu. 8-9.01.1992. Tekirdag, Hasad Yayıncılık. p. 197-204.

Yalcın, S., A. Altan and C. Kocak. 1995. Etlik piliç üretiminde eski yataklıgın yeniden kullanılması olanakları. Uluslararası Tavukçuluk Kongresi. 24-27.05. 1995. Istanbul, Bildiriler. p. 436-44. 